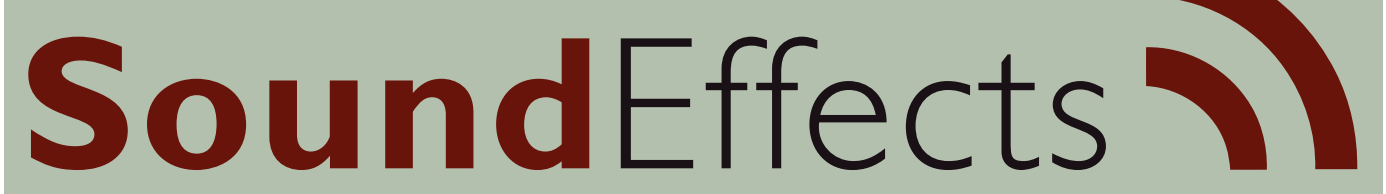

An Interdisciplinary Journal of Sound and Sound Experience

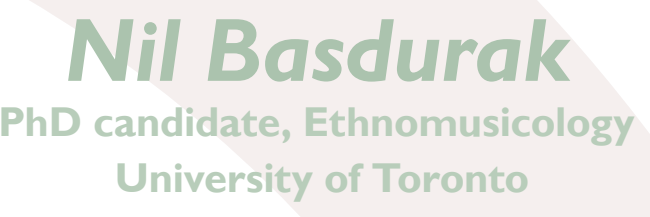

\title{
The soundscape of Islamic populism
}

Auditory publics, silences and the myth of democracy 


\begin{abstract}
Focusing on the failed coup attempt organized by a faction within the Turkish Armed Forces on July 15, 2016, this paper examines the soundscape of Islamic populism (Hadiz, 2016) as embraced by Turkey's ruling Justice and Development Party (AKP) and its affective-auditory publics. Drawing on Althusser's theories of ideology and interpellation concerning the Islamic call (Spadola, 2014), I explore AKP's strategic use of Islamic sound as affect in governmentalizing urban space in order to understand the role that sound played in galvanizing support against the attempted coup. During the first twenty-four hours of the coup attempt, systematically regenerating discursive modes of Islamic rhetoric and sounds, utilizing the narratives of democracy, nationalism, and treachery to mobilize its publics, AKP re-cultivated the already existing polarized identity politics and recreated the sectarian spaces of belonging and otherness. I argue that AKP's appropriation of sonic and aural qualities of Islam - particularly the public recitation of Sala (a form of Islamic call) - purposefully rechannelled the "ethical listening" (Hirschkind, 2006) of pious selves into a politically (re)functionalized listening in the populist reproduction of an Islamic soundscape. Such reproduction of the urban soundscape was responded to in a variety of ways by the mobilized auditory publics in service of the party while creating silenced private spaces of opposition.
\end{abstract}

\title{
Introduction
}

On July 15, 2016, a military coup organized by a faction within the Turkish Armed Forces, allegedly under the orders of the US-based cleric by the name of Fethullah Gülen and his Hizmet (Service) Movement, ${ }^{1}$ formerly in collaboration with, but now at odds with the Justice and Development Party (AKP) government, attempted to take control of the Turkish state. I was about to start my daily routine in the Toronto Reference Library when I received a WhatsApp call from my parents, who live in Ankara - the capital of Turkey. My mother's worried tone of voice suggested that something terrible was going on. She immediately relieved my curiosity and started telling me about the coup attempt. While she called me, an anchorwoman was reading the declaration of the Turkish Armed Forces about the takeover on the Turkish national TV station. The military tanks were already deployed on the Bosphorus Bridge and Taksim Square in Istanbul, while F16 fighter jets were flying in the lowest altitude possible over our apartment building in Ankara. Based on the sounds of the fighter jets, my mother suspected that they were bombing somewhere near our house, and the target was probably the building of the Turkish Intelligence Services. She exclaimed: "The country has turned into a war zone. People are dying in the streets!" After giving a quick description of the course of events, she said: "You have to hear the sounds of the fighter jets! And the mosque across the street 
has just started to broadcast Ezan [or adhan - an Islamic call to prayer]. The government is calling on people to go out to resist the coup attempt!"2

After this quick conversation, I received another phone call from my parents. This time, my father made me listen to the above-mentioned acoustic space. It was a juxtaposition of a form of Islamic call known as Sala followed by announcements coming from mosques, amidst the deafening sonic booms of the F16 fighter jets flying over the city. The announcement following the Sala was asking people to go outside, stating: "In order to defend our democracy against this traitorous coup attempt, our president Recep Tayyip Erdoğan is asking our people to go out and reclaim public squares and airports to show our disapproval of such intervention for the sake of Allah and our state." While I was trying to process this statement embellished with the narratives of democracy, nationalism, treachery, and Islam, the Sala started again followed by a similar announcement.

Audio 1: The sounds of F16 fighter jets, Salas and following announcements from a mosque in Ankara. This sound clip constitutes three short excerpts taken from a longer recording sent to me by my parents.

Crowds had gathered right after President Erdoğan's call to go outside was broadcasted through a FaceTime interview that took place on TV and was further redistributed by the mosques. The phone calls from Turkey were endless. My friends were also sending audio recordings of this clashing soundscape to me via WhatsApp voice messages from Ankara and Istanbul. They all felt that the urgency of the situation could only be conveyed by listening to this horrifying, confusing, clashing acoustic space created by the sonic booms of fighter jets, repetitive Sala recitations with subsequent announcements, and - on top of that - chants of "Allah-u Akbar" from the crowds who went outside to reclaim public squares.

During the night of July 15, the Allah-u Akbar chanting of the protestors and the sounds of the people physically engaged in the resistance against the military forces filled the air together with Sala recitations. By the morning of July 16, the coup attempt was defeated. For the following four weeks, state-sponsored pro-democracy assemblies and rallies - named Demokrasi Nöbeti (Democracy Watch Assemblies) by the AKP government - were held in the major cities. The AKP government claimed that these pro-democracy assemblies were indications that the millet (the nation or the people) was exercising the milli irade (the national will) for its ultimate sovereignty, as it should indeed do in any democratic country. Although this was true to some extent, there was also a large group of people who could not or did not appear in those public spaces (Butler, 2015). The reason was that the government had demarcated milli irade as exclusive to the conservative Sunni Turks by embracing an Islamic nationalist political rhetoric and performativity while disregarding the large Kurdish population and other minority groups as well as major non-Sunni 
Muslim populations such as Alevites, non-Muslim citizens, and the secular people who observe various degrees of religiosity.

A renewed interest in sensorial aspects of the public presence of Islam has benefitted from the earlier works of Habermas (1991), who considered the "modern public sphere as secular" while relegating religion to the private sphere. On the other hand, Talal Asad proposed an alternative perspective on the secular governance of the public and the private spheres. To Asad, both religion and secular powers function to shape certain kinds of sensibilities deploying mental and embodied disciplines (2003), which will eventually affect the human sensorium in important ways (Jouili \& Moors, 2014). This interpretation of the binary understanding of the "private versus public" and "secular versus religious" has created new ways of thinking about Islamic sounds and soundscapes (Mahmood, 2012; Hirschkind, 2006 and 2011; Deeb \& Harb, 2007; Eisenberg, 2013). Following Asadian conceptualization of piety and secularity, Charles Hirschkind defines Islamic soundscape as a "way of reconfiguring urban space acoustically through the use of Islamic media forms" (2006). He emphasizes the ethical aspects of the sound, the sonic source, and the listening activity rather than the political aspects within the Egyptian context and argues that deliberative practices of Islamic sounds "are not oriented toward politics: their purpose is not to influence the formation of state policy or to mobilize voting blocs behind party platforms" (Hirschkind, 2006). Retrospectively, bracketing religion and piety from party politics, Hirschkind in his definition makes two overlooked assumptions: one directly relates to the production of space through Islamic sound as free from politics, and the other is the identification of Muslim subjects as divergent and isolated from politics, which has been proven wrong during the post 2011 political environment in Egypt. Although Hirschkind with his definition of "Islamic soundscape" points to how the Islamist-versus-Islamic distinction obscures the role of politics in Islam - which is always there - his theoretical approach to "the political" does not allow us to understand how populist politics manifested through Islamic sound operate in case of political upheaval, where the politics are manipulated by the antagonistic political cultures.

Ethnomusicologists and anthropologists of sound have already written about the recited Sala's role in the resistance against the July 15 coup attempt (Gill, 2016; Tremblay, 2016; Öğüt, 2016; Köymen, 2017). However, this paper takes a different approach and investigates the overlooked functions of the countrywide Sala recitations, considering them as a means of affective politics of Islamic populism. In his seminal work On Populist Reason, Ernesto Laclau defines populism as a political logic and a performative operation through which "the people" is made, named, and acted upon by "the populists" (2005). In this paper, I argue that the sonic reproduction of urban space through multilayered Islamic calls and announcements during the heated moments of the coup attempt has strategically been utilized as a performa- 
tive and affective operation, through which the AKP government made, named, and acted upon "the people" under the discordant label of "democracy". In this operation, the role of the Sala - as an Islamic "sound mark" (Schafer, 1994) of the resistance - has been twofold. Firstly, it became instrumental in setting an Islamic tone and mood for the democracy defense and created a significant mobilizing effect for the pious, conservative, and nationalist "affective-auditory" publics of AKP while encouraging further Islamic performativity of ordinary people in public spaces. Meanwhile, the Sala had a silencing effect for AKP's counter-publics which constitute a wide range of oppositional populations from various backgrounds, many of whom would later be marginalized and melded into the same pot of treachery as the putschists during a two-year-long state of emergency. Secondly, utilizing the Islamic sound and the "ethical listening" of its pious supporters (Hirschkind, 2006), the AKP government drafted a historical narrative, an epic myth of defense, for its grassroots' pious, conservative, and nationalist base which has long been in a struggle with the Kemalist ${ }^{4}$ secular state's ideology about the state-religion relationship. By defining the soundtrack of the resistance as an Islamic one, AKP orchestrated a social movement against the attempted coup while attributing its achievements to a segment of the population who shares a common history of oppression under Kemalism and previous military interventions, common value orientations towards Sunni Islam and its morality, and common nationalist feelings towards Turkishness.

\section{Antagonistic political culture and emergent Islamic populism in Turkey}

The republican political history of Turkey broadly indicates five main political subgroups that have been antagonistically in conversation with each other, regarding both party politics and social levels. The first four are: French-influenced secularism (laiklik), which has strong ties to Kemalism; ultra-nationalism (milliyetçilik), which prioritizes ethnic Turkishness over other ethnicities; conservatism (muhafazakarlk), mainly the center-right politics which are at odds with the Westernized imagination of the founding principles of the Republic; and Islamism (İlamcilik), which advocates for the rights of the oppressed Muslims as part of a larger Ummah (community of Muslim believers) and is at odds with both Kemalist secularism and conservatism. The fifth subgroup, the Kurdish independence movement, was added to this political history in the 1980 s as a response to Turkish nationalism. Although it is possible to talk about a certain level of fluidity among some of these subgroups, the identity politics in Turkey have been rooted in historically dichotomized constructions of society along the lines of differences in ethnicity, religion, and ideology and projected by aggressive party politics (Tuğal, 2013). Furthermore, the political culture evolving around socially and historically constructed binary oppositions - 
such as modern versus traditional, left-wing versus right-wing, secular versus religious, Sunni versus Alevite, and Turkish versus Kurdish - has eventually created divergently subjective value orientations and political positionalities which have become "predispositions to political actions" (Kavanagh, 1972) by party leaders mostly with populist and authoritarian orientations - and of their loyal voting blocs.

Despite this complex sectarian and antagonistic political culture and the fact that the dichotomies of identity politics are never mutually exclusive, but rather simultaneously operative, it is generally one or the other of the binary opposites that has been projected and enacted upon "the people" by the populist governments. For instance, the Islamic-versus-secular dichotomy has long been manipulated by the political party leaders of both Islamist and secular ideological subgroups as a strategical means of alienating the socio-political subcultures from each other and inducing a feeling of threat against the existence of the other in order to establish an imagined future for the country, based on their ideologies. Therefore, talking about Islamic soundscape within the context of today's Turkey inevitably brings Muslim subjects' binary opposite, the secular, into the discussion. I call this strategical approach to political subject formation (Agamben, 2009) through party politics "populist projection". While considering Turkish-style populist party politics as a function of this political culture, I define AKP's populism as an Islamic one, not directed against the secular state structure, but rather against the totality of the Kemalist ideology which has been establishing an oppressing social system against the public expression of Islam, based on the secular conception of the public space (Habermas, 1991) since the establishment of the Republic. Therefore, I delineate AKP's populism as often being present with an Islamic performative and rhetorical repertoire, and always at play in other ideological phenomena - such as neoliberalism, Islamism and democracy - in responding to the demands of its cross-class base while belligerently repelling its diverse opponents (Hadiz, 2016). Since AKP first came into power in 2002, it has been working towards the realization of an imagined "New Turkey", defined as a conservative democratic country which embraces Islamic value orientations and is at odds with the secular/Kemalist imagination. The political rhetoric and performativity embraced by AKP during and after the attempted coup exemplifies this political orientation.

\section{The soundtrack of the democracy defense: Sala}

Sala is a particular form of Islamic call in the Sunni tradition. It is similar to Ezan (McPherson, 2009), yet has different textual, contextual, and melodic structures, and different functional properties. Traditionally, in Turkey, Sala has been recited as a sonic reminder for Muslims to attend an ongoing event such as a funeral service. Historically, it had also been used as an Islamic call to ask people to join jihad [Islamic 
war], and it was similarly used as a means of communication in the case of conquests of new land during the Ottoman Empire (McPherson, 2009). In his seminal book The Calls of Islam, Emilio Spadola theorizes about the transitivity of Islam, nationalism, and mass mediation within the Moroccan context and outlines functions of Islamic calls. According to Spadola, the call in Islam operates as a foregrounding force of communication in defining "Muslim subjects and societies as communications' material effect" (Spadola, 2014). Drawing from Althusser's theorization of ideology and interpellation ${ }^{5}$ (Althusser, 1970), Spadola argues that the call in Islam is "inseparable from the authority of its mediators," which promises "a capacity for further rituals" (2014). During the attempted coup, countrywide Sala recitations - as a politicized forced conversation - indicate two distinct, yet related authority centers. While God (Allah) constitutes the first authority center - due to the definition of the Islamic call as a reminder of Allah's uniqueness for the Muslims - the state, as a mediating power of the call, constitutes the second authority center.

During the establishment of the Republic of Turkey in 1923, secularism became an explicitly stated, fundamental element of the official state ideology (Tuğal, 2013). In 1924, Islam was institutionalized with the formation of the Turkish Presidency of Religious Affairs (Diyanet İşleri Başkanlığı, hereinafter Diyanet), which had monopoly power over the appointment of religious functionaries such as preachers and imams throughout the country as well as the distribution of sermons. Although the Republic had retained Islam as the state religion, by 1925 it swept away the caliphate, religious courts and schools, and tarikats (religious orders), while introducing the Latin alphabet and Western legal code with a further secular modernization plan. In 1928, the clause about the state religion was eventually removed from the constitution. However, despite the strict appreciation of secularism as a core principle of the Republic, the Diyanet was maintained as the guarantor of the secular state's control over Islam (Heper, 1985; Mardin, 1983; Tuğal, 2013). Today, more than 90,000 mosques operate under the direction of the Diyanet - the majority of which, through reciting the Sala, served as sonic mediators in disseminating the political message of the AKP government during the coup attempt in 2016. Having exclusive power of instrumentalizing the Sala, under the rule of the AKP government the Diyanet acted as one of the main authority centers. It emphasized citizenship as a unity inseparable from Islam and reinforced a political conversation between the state and the Sunni Muslim Turks in an attempt to protect the legitimacy of the AKP government.

Although Turkey is a Muslim-majority country, it has never been an easy task to define Muslim and secular subjects by their normative definitions. The binary oppositions created between Muslim and secular subjects as a result of antagonistic party politics have never left a space for defining a faithful (Muslim) secular subject. Historically constructed politics of difference targeting secular and pious individuals as divided and non-intersecting categories have failed to recognize 
the existence of self-identifying secular Muslims, citizens who are the followers of non-Sunni sects of Islam, non-Muslims, and non-believer citizens. As a normative category, the secular subject has almost been equated to a de facto non-believer subject, although the vast majority of secular citizens in Turkey would self-identify with various degrees of Muslimhood. Such a discrepancy in the identification of pious and secular subjects and the historically constructed antagonism between the political ideologies which speak to either of these groups and the populist structure of party politics, have continuously suppressed and managed how, when, and under what conditions Islam and secularism can be used as a means of political propaganda. Thus, the resistance against the attempted coup mediated by the Islamic populism of the state authority succeeded in setting an Islamic and nationalist tone for the democracy defense while framing and shaping unilateral definitions of Muslimhood and millet (nation) with an underlying reference to the concept of a Muslim ummah. For this purpose, the AKP government reproduced an urban soundscape which was heard as contextually and sonically Islamic, yet functionally populist and Islamist. AKP's Islamism "emanates from a political interpretation of Islam which is based not on the religious faith of Islam, but on an ideological use of religion within the political realm" (Tibi, 2012, vii). Therefore, I assert that such strategical use of Islamic sound in a moment of upheaval cannot be simply considered an Islamic attempt to reproduce urban soundscape, but is rather a populist political attempt to create an epic myth out of this political movement towards the realization of AKP's "New Turkey".

\section{Sonic belonging versus silenced otherness}

Other than Sala recitations, further indications of AKP's Islamic populism can be captured through the Islamic rhetoric embraced by government officials. During the first twenty-four hours of the coup attempt, government officials widely used an Islamic rhetoric to generate an Islamic affective space in making and acting upon "the people". One of the most significant examples of such rhetoric can be observed in the Diyanet's social media accounts. Utilizing Twitter to continue its political conversation with its targeted affective-auditory publics, the Diyanet became instrumental in expanding the reach of its message to a larger population. As a result of Twitter's reciprocity, the reach of the government's Islamic nationalist message continued to create further conversations shaped around the sound of Sala, while accelerating the antagonistic nature of politics of difference. The following tweet from Mehmet Görmez - the head of the Diyanet at that time - on July 15 distinctly shows how AKP's populism operated in conjunction with exclusionary identity politics. 
Dear fellow Muslims; It is our greatest obligation today to do our share in protecting our country's law. The total disregard for our country's and the nation's unity, peace, and well-being and the forcible and violent breach of national will are completely unacceptable. As spiritual guides of our nation, we stand together with you against any kind of illegal and unlawful attempts. I invite you all, from our minarets that are the symbols of freedom, to suppress this great treachery using non-violent means. Minarets will be lit up tonight, and our nation will be called upon to protect their laws with Salas.

By exclusively targeting Muslim citizens in the communication, demarcating the national will to only self-identifying Sunni Turks, and defining the Diyanet as the spiritual guide of "the nation" and minarets as the symbols of freedom, the head of the Diyanet disregarded a large portion of the population who would feel excluded, unsafe, and intimidated by the Islamic call even though this population had not necessarily been supporting the coup attempt. Phenomenological affect theorist, Silvan Tomkins provides a non-binary model of affects as emerging in plural forms out of bodies and asserts that the use of the right affects in the right time and place can launch a political movement (Schaefer, 2015; Tomkins, 2008). Similarly, the Diyanet created the right affects in the right time and place to invite the recipients of the message of the Islamic call to appear in public spaces as a sounding affective community and move within the systems of power, while simultaneously creating silenced private spaces of otherness.

Silence as a political language "implies an active politics of domination and nonparticipation". In processes of denial of expressive practices, silence can "indicate an active listening in control of the production of meaning" (Ochoa Gautier, 2015). Therefore, in cases of political upheaval, production of silenced and sounding communities cannot be thought of separately from histories of oppression, discrimination, and exclusion. During the coup attempt, both sides of this discriminative history made meanings out of the acoustic space based on the history and the future imagination they consider themselves as belonging to. During the first-year commemoration of the failed coup attempt, I was in Istanbul for my field research and had the opportunity to talk to people from different backgrounds with different views about the coup attempt and the way the government handled this chaotic situation. During a private conversation, an anonymous interviewee who identifies as a secular, Turkish woman who is against any military and/or civil intervention to the democracy in Turkey, expressed her feelings about how she has felt silenced and/or preferred to stay silent due to the acts of the putschists, the mobilized crowds, and the AKP government as follows

An Islamic soundscape created by the government on purpose against the horrifying sounds of the fighter jets, which were so loud and confusing in a way that could make one think it was the sound of bombs. It was scary! But the enforcement of Sala 
recitations by the government was equally scary. The Salas did not stop for almost two days, although during the first twenty-four hours of the coup attempt, they were more frequent. After hearing the Sala for the first time that night, I thought that jihad had been declared by the government. On top of that, Allah-u-Akbar chanting mobilized crowds were somehow supporting my initial feelings against the sonic environment created. To me, it definitely did not feel safe, not only because of the Islamic nature of the soundscape, but also because of what this soundscape would mean for the future of the country. I could not go out and neither did I want to go out and be part of this. We were not able to get clear information about who the coup plotters were. Some people were saying that the coup attempt was staged by the government to consolidate its power, and some were saying that the coup attempt was organized by Fetullah Gülen. Of course, this indicates the distrust of a certain segment of the society towards the media and the government.

Focusing on the nature of religious ritual and its mediations, Spadola argues that the call in Islam "assumes a capacity of rituals and attendant media to communicate and expects that Muslim bodies will transmit their force" (2014). The Sala and the Islamic populist rhetoric embraced by the authorities reconfigured territorial and social boundaries among citizens and eventually recreated urban sonic environments as affective spaces of belonging, in which Islamic auditory and performing practices of Muslim subjects were accommodated despite strict limitations and/or prohibitions placed on such practices in public spaces by Turkey's secular constitution. These practices and performances included collective public namaz (Islamic ritual prayers), Allah-u Akbar chanting and recitation of prayers from the Kuran (Quran), and - most symbolically - public zikirs performed by adherents of tarikats (religious Sufi orders) during the pro-democracy assemblies. Muslim spirituality is mediated by bodily practices (Mahmood, 2001; Hirschkind, 2001), and zikir (dhikr) is one the most significant of these. Zikir is the ritual invocation of divine authority and power by Muslims through the repetition of the Most Beautiful Names of God (Asma al-Husna), accompanied by the performance of chanting and sounding bodily movements collectively known as sama (audition) (Shannon, 2006). In zikir, aesthetic and kinesthetic stimuli, such as ilahis (religious songs), repetitive inhalation and exhalation, and bodily movements produce an experience of temporal transformation that participants describe as "ecstasy" (Shannon, 2006). This temporal transformation of a Muslim body through zikir further suggests a capacity to transform public space from secular to Islamic, at the same time generating affect and emotions. During the aftermath of the defeated coup, zikir performances by various tarikats took place in major public squares and in Millet Mosque situated in the Presidential Complex built by the AKP government in Ankara.

Since 1925, tarikats have been considered constitutionally illegal religious organizations, and their activities in public spaces have been strictly banned under secular law. However, from the 1950s, religious orders began to flourish again, yet they 
kept their activities mostly private and underground. Political parties, on the other hand, began to regard tarikats as significant sources for votes. They built close relationships with their leaders and cemaats (communities of followers). As a result of this profitable relationship, despite the constitution's clear statement about their illegal status, tarikats acquired a formidable reputation, and therefore the implementation of the constitution became almost impossible. Similarly, the AKP government has established close relationships with tarikats over the last two decades in order to obtain voting blocs.

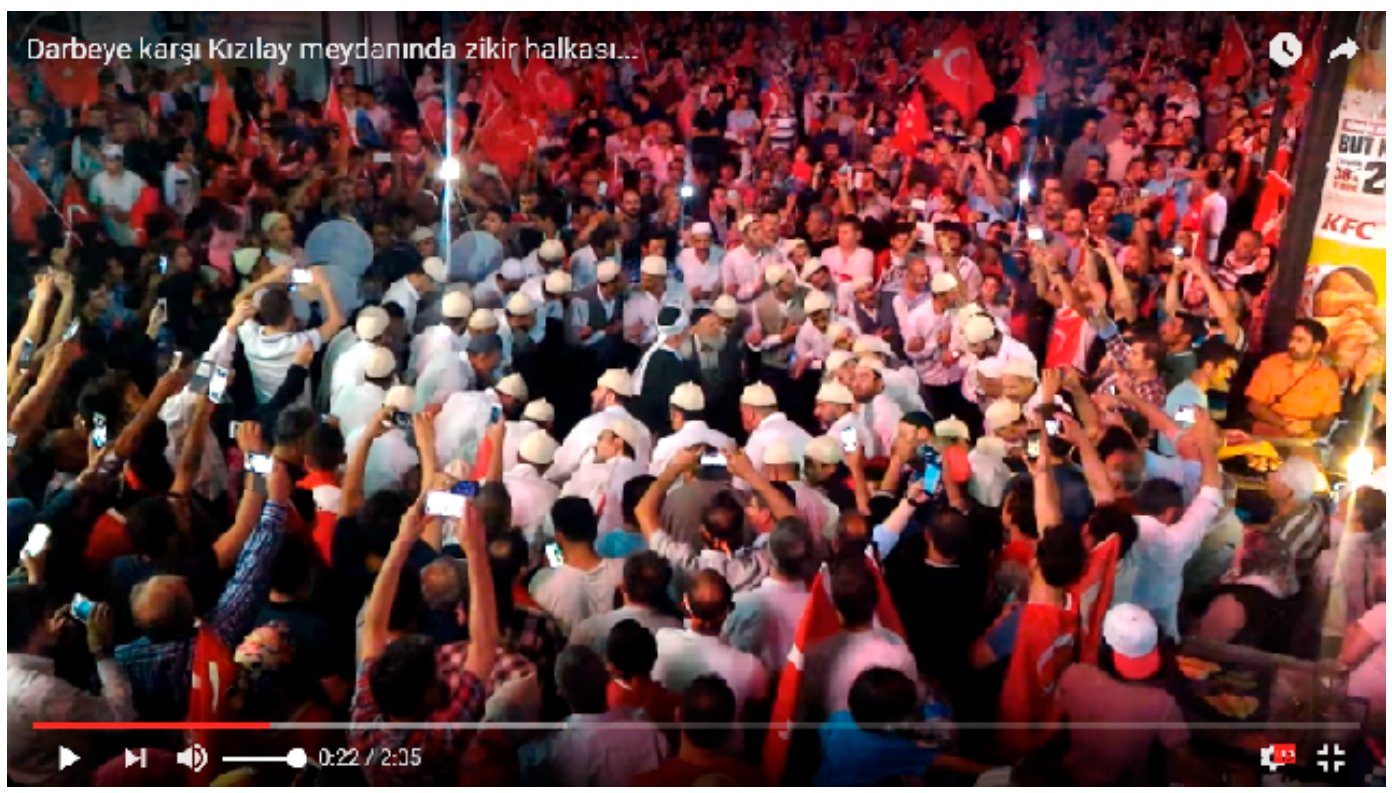

Figure 1: Zikir circle at a Democracy Watch assembly in Kizulay Square in Ankara. Screen shot from the video. ${ }^{6}$

Right after the defeat of the attempted coup, a controversial public zikir was performed by the followers of an unnamed tarikat in Kizllay Meydanı, the main public square in Ankara. This example shows how such ritual performances in highly polarized and politicized assemblies might function to gather the crowds around Islamic performativity by employing the power of uniting "the people" under the name of Allah, as well as orchestrating and motivating further participation by the audience in the Islamic sonic reproduction of public space. While creating a "particular register of affect sensed in the body" through the practitioners' voice "as the words are melodically sounded", zikir also evokes emotions as affect through performances which are perceptually "framed by the concepts and values attached to those practices" (Howell, 2015). Therefore, the ritual performance of zikir in the context of politicized social assemblies gives the practitioners an opportunity to openly self-identify through their religious affiliations and operates as a political performative text. 
In a moment of political upheaval, such spiritual performativity also suggested further functions and implications. On the one hand, the emotional display of zikir groups created a temporal sonic spatiality while reproducing "nested spaces" (Smalley, 2007) of belonging and piety. Within these nested spaces of religiosity, the human body and voice act as agentive material forms with the power to evoke affect (Howell, 2015) while mediating the spaces nested in each other through the spiritual power. Therefore, sonic production of such nested spaces of religiosity is by definition performed, affective, and agentive. On the other hand, the affective spaces created through Islamic performances and sounds have caused negative emotional displays of the metaphorically silenced, mostly secular segments of the society and increased an already existing secular anxiety towards Islam's public appearance. These conflicting and separately constructed emotional-affective spaces of sound and silence worked on multiple aesthetic, political, and spiritual layers to further create literal binary spaces of fear and courage, treachery and patriotism, and belonging and otherness while organically alienating two antagonistic segments of the society from each other.

\section{Drafting an epic myth of democracy for the "New Turkey"}

Traces of history and narratives describing important events permeate all spheres of society and cultural life in various forms of media which exist in embodied symbolic forms as artifacts or ideological texts which are mediated by carriers of memory and have the capacity to generate affects. Therefore, cultural memory can be considered as a kind of institution which is exteriorized, objectified, and stored away in different forms and always in relation to the political.

\footnotetext{
"For politicians and political movements, history can be an important source of framing device. The rhetorical use of historical references can establish a line of tradition. Political actors can contextualize their connection to the political entity they seek to represent by indicating a historical analogy between the present and a given historical occurrence. Alternately, they can place themselves in opposition to a set of characteristics embodied by a historical individual, event, or movement. Political uses of historical references are, therefore, symbolic in aim and are not about history, but memory. It is not a question of validity, but relevance" (Wijermars, 2018).
}

Thus, in populist realms of politics, the events of the past are ready to be recalled from the archival memory of the collective, to be repurposed and endowed with new meanings, to be reactivated, and to generate affects (Assmann, 2008). This reactivation is governed by the questions of which memories of the past have been chosen to bolster or complement a present condition, by whom and in what kind of socio-political circumstances they are reactivated and create new affective spaces. How is cultural memory linked to political legitimacy? 
The attempted coup, the state-sponsored Salas, and the Diyanet's social media accounts have similarly been used to recall the silences of the past and to endow these memories with new meanings. In the early morning of July 16, after the defeat of the putschists, Mehmet Görmez posted a second tweet, particularly emphasizing the changing position of the military - self-proclaimed safeguard of the secular state - against the political parties that had embraced an Islamic worldview. His tweet stated: "I thank Allah for blessing us with the sound of Sala that silenced coups when it was the coups that silenced ezan once upon a time." Referring to four military coups of the past which shut down the Islamist political parties, the predecessors of AKP, Görmez affirmed that the mobilized affective-auditory publics of AKP have resisted against the coup plotters, a faction within the military, while pointing to the totality of Turkey's past military oppression against the "Muslims". The Sala recitations and the Diyanet's tweets therefore became evidence of collective remembrance, preparing them to be transferred from one situation to another and transmitted from one generation to another in the making of a counter epic myth of "democracy".

Although the sounding and the silenced groups mostly shared common feelings regarding the cruciality of democratic rule in Turkey and a common sense that a military coup would take the country backward, the recited Sala brought up strong contentions between the groups as to what Turkish democracy is, who "the people" defending "democracy" are, and whom "democracy" was meant to serve. It is this literal space between belonging and otherness that defined which bodies had the right to "appear" in public spaces, which bodies were meant to be a part of the political movement, and which bodies were to be silenced and/or excluded from the making of the epic myth. According to Judith Butler, "democracy" is a discursive term due to the strategic alliances concerning who participates in democracies, although theoretically, it implies "the power of self-determination" (2015). "The people" are not a given population; instead, they are constituted by the lines of demarcation that we tacitly or explicitly establish. Thus, every formation of "the people" is partial, and total inclusiveness is not possible due to group interests conflicting with common interests. This assertion of "the people" often implies "a declaration of hegemony" (Butler, 2015). In drafting a myth of democracy during and after the attempted coup, the AKP government's utilization of the notions of "Millet" and "the people" was not fully inclusive, but rather constituted a select population of Turkish conservatives, ultranationalists, and Islamist subgroups. Therefore, construction of the democracy myth based on "the national will" in the name of "the people" while silencing and excluding its "others", empowered the AKP government to legitimize its rule. 


\section{Conclusion}

"Islamic sound" is a "self-descriptive" term which refers to "both the sounds that performers and/or audiences consider as linked to Islam as well as the sounds that participants in public debate label as Islamic" (Jouili \& Moors, 2014). Islamic sounds are not always necessarily defined by the sound source but are also conceptualized as Islamic according to how the listeners of these sounds make meaning out of them, interpret them, and place them in the daily life as Islamic. What is perceived as an Islamic sound is, therefore, a subjective phenomenon that might change depending on where these sounds are heard, who listens to them, what the sound source is, and what kind of power dynamics are in play in the projection of the sounds. I define "Islamic soundscape" as a tacitly or explicitly organized affective space produced through political and/or ethical actions by ordinary Muslims in episodic moments. In other terms, an Islamic soundscape is constructed through the oral and auditory practices of ordinary Muslims that may or may not be related to the state or other power brokers. Such reproductions of soundscapes enable Muslim subjects to exercise political agency through individual sounding and listening practices in connection with public interactions and to shape their collective existence (Arendt, 1958). On the other hand, a populist reproduction of an Islamic soundscape can only be organized through authoritative politics, namely resources only available to public authorities of the collectivity who explicitly connect Islamic sounds to symbols, practices, and discourses of their political agenda(s). Thus, populist construction of Islamic soundscapes can only be realized by the state, religious organizations such as tarikats and their constituents, and institutions, as well as the Islamist organizations who aspire to establish a state but have not yet reached and may never reach that point.

I consider the discussed Sala recitations mediated by the state authority - the Diyanet and the AKP government - as rhetorical, performative, affective, and sonic manifestations of Islamic populism. As the ethical and political motivations of the faith of Islam and the religionized politics of Islamism suggest different sociopolitical conditions, the soundscape produced under the faith of Islam and political Islamism should be considered as divergent affective constructions. Although an Islamic soundscape and the soundscape of Islamic populism might coexist and be unpredictably transitional, this does not suggest that they are the same with respect to affective capacity, character, and function. Based on this theorization, in Turkey's case, the Islamist use of Islamic sounds functioned as an infrastructural deployment of exclusionary politics to make, name, and act upon "the people" and to mobilize the blocs that vote for the ruling AKP, with a capacity to legitimize a state-driven continuous project of Islamization. It was also utilized to silence the opponents of the AKP government, and to draft a brand-new epic myth of democ- 
racy for its affective-auditory publics and loyal grassroots base. President Erdoğan's honest expression of his feelings towards the defeated coup in the statement, "This coup attempt is a gift to us from Allah", and the following two-year-long state of emergency $^{7}$ declared in July 2016 to facilitate the purges and detainments of suspected and unwanted political actors regardless of their affiliation with the putschists, supports this idea. Such authoritative mediation of Islamic sounds under these superficial conditions and the agency of AKP's affective-auditory publics cannot be considered isolated from politics and cannot be relegated to a single definition of the faith of Islam.

\section{Acknowledgements}

I would like to thank two anonymous reviewers for their insightful comments and suggestions which helped me present my argument more clearly. I would also like to thank Farzaneh Hemmasi, Nadia Younan, Ahsen Hüseyin Akdal, Kousha Nakhaei and an anonymous reader for their comments on earlier versions of this article and Maya Berger for the language editing.

\section{References}

Agamben, Giorgio. (2009). “What is an Apparatus?” and Other Essays. D. Kishik \& S. Pedatella (Trans.), Stanford, CA: Stanford University Press.

Althusser, Louis. (1970). Ideology and Ideological State Apparatuses (Notes Towards an Investigation). In Slavoj Zizek (Ed. 1994) Mapping Ideology (100-139). London: Verso.

Arendt, Hannah. (1958). The Human Condition. Chicago, IL: University of Chicago Press.

Asad, Talal. (2003). Formations of the Secular: Christianity, Islam, Modernity. Stanford, CA: Stanford University Press.

Assmann, Jan. 2008. “Communicative and Cultural Memory”. In Astrid Erll \& Ansgar Nünning (Eds.) Cultural Memory Studies: An International and Interdisciplinary Handbook, 109-118. Berlin: Walter de Gruyter.

Butler, Judith. (2015). Notes Toward a Performative Theory of Assembly. Cambridge, MA: Harvard University Press.

Deeb, Lara \& Harb, Mona. (2007). Sanctioned Pleasures: Youth, Piety and Leisure in Beirut. Middle East Report, (245), 12-19. https://doi.org/10.2307/25164816

Eisenberg, Andrew J. (2013). "Islam, Sound and Space: Acoustemology and Muslim Citizenship on the Kenyan Coast". In Georgina Born (Ed.) Music, Sound and Space: Transformations of Public and Private Experience. New York, NY: Cambridge University Press.

Esen, Berk \& Gumuscu, Sebnem. (2017). Turkey: How the Coup Failed. Journal of Democracy, 28(1), 59-73. https://doi.org/10.1353/jod.2017.0006

Gill, Denise. (2016, August 10). Turkey's Coup and the Call to Prayer: Sounds of Violence Meet Islamic Devotionals. The Conversation. Retrieved from https://theconversation.com/turkeys-coup-andthe-call-to-prayer-sounds-of-violence-meet-islamic-devotionals-63746

Habermas, Jürgen. (1991). The Structural Transformation of the Public Sphere: An Inquiry into a Category of Bourgeois Society. Cambridge, MA: MIT Press. 
Hadiz, Vedi R. (2016). Islamic Populism in Indonesia and the Middle East. Cambridge: Cambridge University Press.

Morris, Chris. (2018, June 18). Reality Check: The numbers behind the crackdown in Turkey. BBC. Retrieved from https://www.bbc.com/news/world-middle-east-44519112

Hefner, Robert W. (Ed.). (2005). Remaking Muslim Politics: Pluralism, Contestation, Democratization. Princeton, NJ: Princeton University Press.

Heper, Metin. (1985). The State Tradition in Turkey. Huntingdon, QC: Eothen Press.

Hirschkind, Charles. (2006). The Ethical Soundscape: Cassette Sermons and Islamic Counter-publics. New York, NY: Columbia University Press.

Howell, Julia Day. (2015). Revival Ritual and the Mobilization of Late-modern Islamic Selves. Journal of Religious and Political Practice, 1(1), 47-57. https://doi.org/10.1080/20566093.2015.1047691

Jouili, Jeanette S. \& Moors, Annelies. (2014). Introduction: Islamic Sounds and the Politics of Listening. Anthropological Quarterly, 87(4), 977-988. George Washington University Institute for Ethnographic Research, from Project MUSE database. doi: 10.1353/anq.2014.0064

Kavanagh, Dennis. (1972). Political Culture. London: Macmillan.

Köymen, Erol. (2017). From Coups that Silence Ezan-s to Ezan-s that Silence Coups!: Sonic Resistance to the 2016 Turkish Military Coup. Current Musicology, (101), 99-124, 152.

Laclau, Ernesto. (2005). On Populist Reason. London: Verso.

Mahmood, Saba. (2012). Politics of Piety: The Islamic Revival and the Feminist Subject. Princeton, NJ: Princeton University Press. (Original work published 2005).

Mardin, Şerif. (1983). Religion and Politics in Modern Turkey. In James Piscatori (Ed.), Islam and the Political Process (138-159). Cambridge: Royal Institute of International Affairs.

McPherson, Eve. (2009). The Beautiful Voice: Voice Quality and the Turkish Call to Prayer (PhD dissertation). University of California Santa Barbara, Santa Barbara, CA.

Ochoa Gautier, Ana María. (2015). "Silence.” In David Novak and Matt Sakakeeny (Eds.) Keywords in Sound. Durham and London: Duke University Press. https://doi-org.myaccess.library.utoronto. $\mathrm{ca} / 10.1215 / 9780822375494$

Öğüt, Evrim Hikmet. (2016). "Soundscape of a coup d'état," Sound Matters Blog. Society for Ethnomusicology. https://soundmattersthesemblog-wordpress-com.myaccess.library.utoronto.ca/2016/09/ 06/evrimhikmet-ogut-soundscape-of-a-coup-detat

Schaefer, Donovan O. (2015). Religious Affects: Animality, Evolution, and Power. Durham and London: Duke University Press.

Schafer, R. Murray. (1994). The Soundscape: Our Sonic Environment and the Tuning of the World. Rochester, NY: Destiny Books. (Original work published 1977).

Shannon, Jonathan. (2006). Among the Jasmine Trees: Music and Modernity in Contemporary Syria. Middletown, CT: Wesleyan University Press.

Smalley, Denis. (2007). Space-form and the Acousmatic Image. Organised Sound, 12(1), 35-58. https:// doi.org/10.1017/S1355771807001665

Spadola, Emilio. (2014). The Calls of Islam: Sufis, Islamists, and Mass Mediation in Urban Morocco. Bloomington and Indianapolis, IN: Indiana University Press.

Tibi, Bassam. (2012). Islamism and Islam. New Haven, CT: Yale University Press.

Tomkins, Silvan S. \& Karon, Bertram P. (2008). Affect, Imagery, Consciousness: The Complete Edition. New York: Springer.

Tremblay, Pınar. (2016, July 25). How Erdoğan used the power of the mosques against coup attempt. Al-monitor. Retrieved from http://www.al-monitor.com/pulse/originals/2016/07/turkey-coupattempt-erdogan-mosques.html

Tuğal, Cihan. (2013). Islam and the Retrenchment of Turkish Conservatism. In Asef Bayat (Ed.) Post-Islamism: The Changing Faces of Political Islam (109-131). New York, NY: Oxford University Press. Wijermars, Mariëlle. (2018). Memory Politics in Contemporary Russia: Television, Cinema and the State. London: Routledge. https://doi-org.myaccess.library.utoronto.ca/10.4324/9781351007207 


\section{Notes}

1 Fethullah Gülen is a Muslim cleric who created the Hizmet (Service) Youth Movement to counteract secular and socialist tendencies in 1966. Following the 1980 coup and benefiting from the political environment in which Islam had been shown as having a closer relationship with the secular state, he and his disciples set up hundreds of Islamic-oriented schools, media companies, civil society groups, and businesses, both inside and outside Turkey. Gülen also sought to quietly place his followers within Turkey's bureaucracy. In 2004, the National Security Council formally identified Gülen as a threat to state security, citing his leaked sermons and testimony from former members of his movement. The AKP government, however, did not take any action and pocketed the Council's recommendations until the AKP finally had a fall out with Gülen in late 2011 (Esen \& Gumuscu, 2017). After the defeated coup attempt in July 2016, Gülen and his followers were declared to be a terrorist organization named FETÖ and to be the plotters behind the coup.

2 All quotes from the author's family members and interviewees as well as from Turkish political and religious figures have been translated from Turkish into English by the author.

3 Allah-u Akbar - also known as Tekbir in Turkish and Takbir in Arabic - is the Arabic phrase translated into English as "God is the greatest".

4 Kemalism refers to the ideology of Turkey's founding president, Mustafa Kemal Atatürk, who imagined the Republic of Turkey as a modern, secular, and social state.

5 Louis Althusser suggests that "ideology 'functions' in such a way that it 'transforms' the individuals into subjects." He calls this operation interpellation or hailing "which can be imagined along the lines of the most commonplace everyday police hailing: 'Hey, you there!'” Upon hearing the exclamation of the police officer and immediately responding to the hail by turning around, the individual "becomes a subject" (Althusser, 1972).

6 Zikir in Ankara's Kızılay Square. See Can, Serafettin. (2016, July 19). Darbeye karşı Kızılay meydanında zikir halkas1 [Dhikr circle against the coup attempt in Kizılay square.] [Video file]. Retrieved from https://www.youtube.com/watch?v=3wp9sNW7dJ4.

7 During the state of emergency (July 2016 - June 2018), the government used its majority votes in the parliament to pass decree laws which target not just the putschists who had relations with Fethullah Gülen, but also Kurdish activists, politicians, academicians, students, judges, universities, and media channels. By 2018, it was reported that some 235,000 people had had their passports canceled, 511,000 people had been taken into custody, of which more than 50,000 had been arrested. 6,000 people in academia had lost their jobs and more than 107,000 people, including soldiers, police officers, judges, and teachers had been dismissed by emergency decree (Morris, 2018). 